\title{
Mycoflora Associated with Groundnut Seeds Collected from Selected Groundnut Growing Districts of Telangana State, India
}

\author{
G. Adithya ${ }^{1 *}$, B. Rajeshwari ${ }^{1}$, K. Keshavulu ${ }^{2}$, H. Sudini ${ }^{3}$ and Y. Swathi ${ }^{1}$ \\ ${ }^{1}$ PJTSAU, Telangana, India \\ ${ }^{2}$ TSSCA, Telangana, India \\ ${ }^{3}$ ICRISAT, Patancheru, India \\ *Corresponding author
}

\begin{tabular}{|c|c|}
\hline & A B S T R A C T \\
\hline & \multirow{9}{*}{$\begin{array}{l}\text { Groundnut is an important food legume in several developing and developed countries. In } \\
\text { India, Telangana state is one of the major groundnut growing states. A survey was } \\
\text { conducted to collect a total of } 72 \text { groundnut pod samples at the time of harvesting from } \\
\text { farmers and local markets in four districts, namely; Karimnagar, Warangal, Nizamabad, } \\
\text { Mahabubnagar during } 2015-16 \text {. These samples studied for detection of seed mycoflora by } \\
\text { Agar plate method as recommended by ISTA. The major mycoflora associated with seeds } \\
\text { belongs to five fungal genera such as Aspergillus, Fusarium, Alternaria, Macrophomina, } \\
\text { Penicillium and total incidence was ranged from } 0.67 \%-47.11 \% \text {. Samples collected } \\
\text { from farmers were highly infected with different mycoflora compared to the samples } \\
\text { collected from market. A. niger was predominant ( } 47.11 \%) \text { while, the least was } \\
\text { Penicillium }(0.44 \%) \text {. Out of four districts surveyed, the total incidence of mycoflora was } \\
\text { high in Mahabubnagar and low in Nizamabad. The fungal species A. niger was found } \\
\text { associated with all the collected samples of four districts at maximum incidence when } \\
\text { compared to other fungal species. Current results imply the urgent need for application of } \\
\text { management measures against different seed borne fungi to maintain the quality of }\end{array}$} \\
\hline & \\
\hline Groundnut, & \\
\hline $\begin{array}{l}\text { Seed mycoflora, } \\
\text { Telangana. }\end{array}$ & \\
\hline Article Info & \\
\hline & \\
\hline Available Online: & \\
\hline 10 July 2017 & \\
\hline & \\
\hline
\end{tabular}

\section{Introduction}

Groundnut (Arachis hypogaea L.) is an important oil seed crop in India. It contains oil to an extent of $48-51 \%$. In India, the crop is grown to an extent of $5.53 \mathrm{M}$ ha with a production of $9.67 \mathrm{M} \mathrm{t}$ and productivity of $1750 \mathrm{~kg} \mathrm{ha}^{-1}$ (FAOSTAT, 2013 - 14).

In Telangana state, the crop is grown to an extent of $0.21 \mathrm{M}$ ha with a production of $0.355 \mathrm{M} \mathrm{t}$ and productivity of $1320 \mathrm{~kg} \mathrm{ha}^{-1}$ (Statistical year book of Telangana, 2015). Groundnut being an oil seed, it contains lesser amount of carbohydrate than cereals but more amount of oil and protein and are likely to be breakdown into simple sugars and amino acids which is essential for germinating seed as an energy source. Ramamoorthy and Karivaratharaju (1989) noticed that progressive decrease in oil and protein content and an increase in free fatty acids in the stored kernels than in the pods because of the invasion of storage fungi to kernels.

Increasing the storage period of groundnut seeds upto nine months decreases the viability, while pathogen activity, moisture and sugar content in seeds increase gradually. 
Groundnut seeds are rich in mono unsaturated fats, the type of fat that is emphasized in the healthy heart mediterranean diet.

Seeds are generally associated with certain saprophytic or parasitic micro-organisms which perpetuate in the seed lots on the advent of favourable conditions. Groundnut seeds are highly susceptible to fungi such as, Rhizopus, Aspergillus flavus, Penicillium, Fusarium. Infection of groundnut by species of Aspergillus occurs both at pre-harvest and post-harvest stages (Dharmaputra et al., 2003, Craufurd et al., 2006 and Goncales et al., 2008).

Groundnut plants are highly susceptible to fungal contamination, including toxin producing fungi. However, toxigenic fungal pathogens are important constraints to the production of the crop, affecting the quality of the seeds during storage.

Generally there are several toxigenic fungi types, but the predominant fungi Aspergillus, Fusarium and Alternaria. Post - harvest conditions favour infestation during storage which may lead to production of different mycotoxins.

Mould fungi are also known to produce mycotoxin (Rodricks, 1976). Many workers have detected different mold fungi and their toxin production ability in stored grains, which deteriorate seed products (Afjal et al., 1979, Vedahayagam et al., 1989).

The objective of the present study was designed to examine the predominant fungal species which causes storage losses. This knowledge of the distribution of contamination by fungal species in the selected regions is helpful to follow reduction strategy in future (Bankole and Adebanjo, 2003).

\section{Materials and Methods}

\section{Collection and processing of seed samples}

Groundnut seeds were collected from farmers and local markets of selected districts (Karimnagar, Nizamabad, Mahabubnagar and Warangal) of Telangana state and the mycoflora associated with seeds were detected by following agar plate (Musket, 1948; Agarwal, 1976; ISTA, 1966) method. In each district, three farmers and three markets were chosen based on the groundnut growing locations. Three samples were collected from each farmer and market and a total of 18 samples were collected per each district. A total of 72 samples were collected from the four districts and assessed for seed mycoflora. Approximately $1 \mathrm{~kg}$ of pods were collected from each, brought to the laboratory and dried in paper bags. Pods were then hand shelled and divided into sub samples. These samples were used for examination of seed mycoflora.

\section{Detection of seed mycoflora}

\section{Agar plate method (ISTA, 1966)}

Potato Dextrose Agar (PDA) was prepared and sterilized in an autoclave. About $20 \mathrm{ml}$ of the medium was distributed to each of the sterile Petri plate under aseptic conditions. Groundnut seeds were transferred to the plates containing PDA medium. Ten seeds per plate were placed at equidistance in a circular fashion. Four hundred seeds from each sample were placed in the plates in four replications. The Petri plates were incubated at $25 \pm 2^{\circ} \mathrm{C}$ in the incubator for seven days and observed every day for the growth of fungi. Per cent infection was assessed as suggested by Jha (1995) and the per cent incidence of each species was calculated as follows. 
No. of seeds colonized in each plate by a particular fungal species

Total fungal

Colonies $(\%)=$ $\mathrm{x} 100$

Total number of seeds in each plate

\section{Potato Dextrose Agar (PDA) medium}

Peeled potato pieces were boiled in $500 \mathrm{ml}$ of distilled water in a $1000 \mathrm{ml}$ beaker till the pieces got softened and the extract were collected in a beaker by sieving through a double layered muslin cloth. Agar - agar was melted in another $500 \mathrm{ml}$ of distilled water in $1000 \mathrm{ml}$ beaker into which $20 \mathrm{~g}$ dextrose was added. The final volume of the medium was made up to $1000 \mathrm{ml}$ by adding sterile distilled water. The $\mathrm{pH}$ of the medium was adjusted to 6.8 with $0.1 \mathrm{NaOH}$ or $0.1 \mathrm{~N} \mathrm{HCl}$ as the case may be with the $\mathrm{pH}$ meter. The medium was sterilized in an autoclave at 15 psi for 15 minutes.

\section{Frequency of groundnut seed contamination}

After keeping the seeds for incubation data were recorded on the number of infected and non-infected kernels. The frequency of different mycoflora associated was determined by proportion of kernels contaminated by each fungal species to the total number of kernels plated.

\section{Isolation and identification of fungal species}

Fungi identification was carried out based on macro morphological characteristics like surface coloration of colonies and colony texture and micro morphological characteristics like conidial head, conidia shape and shape of vesicle. Isolates were observed and identified based on morphological feature used by Cotty, 1994, Eghel et al., 1994, Kurtzman et al., 1997,
Okuda et al., 2000. Fungal colonies that grew rapidly and produced white, yellow, yellow brown, brown to black or shades of green, mostly consisting of adence felt of erect conidiophores were classified as Aspergillus species. Medium, creamy white or white colonies with puffed growth sometimes. The colony color may vary creamy white/white to light orange colonies, dense mycelial/hyphal growth are categorized as Fusarium species. Grey white/grey colour to black color suppressed colonies. In some isolates aerial mycelium also observed. Microconidia also observed and after sclerotial formation the entire colony turn into black color were classified as Macrophomina species. On the other hand, grey to green color suppressed colonies were present. Initial creamy white to light green color colonies with fast growing were classified as Penicillium. Initially grey/white/black color colonies, dense hyphal colonies with supplemental growth were categorized as Alternaria species.

\section{Results and Discussion}

The incidence of seed borne fungi associated with groundnut kernels varied among different districts surveyed. The seeds are the basic input in agriculture and it plays vital role in establishment of a healthy crop. Seed mycoflora greatly influences the germination and establishment of crop stand. In our study, the results indicate that a total of six fungal species viz., A. flavus, A. niger, Fusarium, Alternaria, Macrophomina, Penicillium were found to be associated with the seeds of groundnut. The total incidence was ranged from $0.67 \%$ - $47.11 \%$. Samples collected from farmers were highly infected with different mycoflora when compared to samples collected from market. Out of these six fungal species $A$. niger was predominant $(47.11 \%)$ while, the least was Penicillium $(0.44 \%)$. Out of four districts surveyed the total incidence of mycoflora was high in 
Mahabubnagar and low in Nizamabad. The fungal species $A$. niger was found to be associated with all the collected samples of four districts at maximum incidence when compared to other fungal species (Tables 1 and 2).

\section{Seed mycoflora of farmer samples}

Among the samples collected from farmers (Table 1), highest incidence was in Mahabubnagar (84.78 \%) followed by Warangal (80.12 \%), Karimnagar (72.23 \%) and Nizamabad (56.68 \%) district. Samples collected from Mahabubnagar district were high incidence of fungal species with $A$. niger (47.11\%) followed by A. flavus (34.44\%), Alternaria (0.89 \%), Penicillium (0.89\%),
Fusarium (0.78 \%) and Macrophomina. Samples collected from Warangal district were high incidence of fungal species with $A$. niger $(43.55 \%)$ followed by A. flavus $(32.22$ $\%)$, Fusarium (1.90\%), Penicillium (1.00\%), Macrophomina $(0.78 \%)$ andAlternaria $(0.67$ $\%)$. Samples collected from Karimnagar district were high incidence of fungal species with $A$. niger $(43.11 \%)$ followed by A. flavus (25.56 \%), Fusarium (1.00 \%), Macrophomina (1.00\%) Alternaria $(0.89 \%)$ and Penicillium (0.67\%). Samples collected from Nizamabad district were high incidence of fungal species with A. niger (39.11\%) followed by A. flavus (14.67\%), Fusarium (0.78 \%), Penicillium (0.78 \%), Macrophomina $(0.67 \%)$ and Alternaria $(0.67$ \%) (Fig. 1).

Table.1 Extent of groundnut seed mycoflora in fresh harvest at farmers' level collected from Karimnagar, Warangal, Nizamabad, Mahabubnagar districts of Telangana

\begin{tabular}{|c|c|c|c|c|c|c|c|}
\hline DISTRICTS & A. niger & A. flavus & Fusarium & Alternaria & Macrophomina & Penicillium & TFC (\%) \\
\hline Karimnagar & $\begin{array}{l}43.11 \\
(41.00)\end{array}$ & $\begin{array}{l}25.56 \\
(30.30)\end{array}$ & $\begin{array}{l}1.00 \\
(5.98)\end{array}$ & $\begin{array}{l}0.89 \\
(5.70)\end{array}$ & $\begin{array}{l}1.00 \\
(5.97)\end{array}$ & $\begin{array}{l}0.67 \\
(5.25)\end{array}$ & 72.23 \\
\hline Warangal & $\begin{array}{l}43.55 \\
(41.20)\end{array}$ & $\begin{array}{l}32.22 \\
(34.54)\end{array}$ & $\begin{array}{l}1.90 \\
(7.61)\end{array}$ & $\begin{array}{l}0.67 \\
(5.26)\end{array}$ & $\begin{array}{l}0.78 \\
(5.45)\end{array}$ & $\begin{array}{l}1.00 \\
(5.97)\end{array}$ & 82.12 \\
\hline Nizamabad & $\begin{array}{l}39.11 \\
(38.65)\end{array}$ & $\begin{array}{l}14.67 \\
(21.43)\end{array}$ & $\begin{array}{l}0.78 \\
(5.51) \\
\end{array}$ & $\begin{array}{l}0.67 \\
(5.33)\end{array}$ & $\begin{array}{l}0.67 \\
(5.25)\end{array}$ & $\begin{array}{l}0.78 \\
(5.51)\end{array}$ & 56.68 \\
\hline Mahabubnagar & $\begin{array}{l}47.11 \\
(43.46)\end{array}$ & $\begin{array}{l}34.44 \\
(35.85)\end{array}$ & $\begin{array}{l}0.78 \\
(5.51)\end{array}$ & $\begin{array}{l}0.89 \\
(5.62)\end{array}$ & $\begin{array}{l}0.67 \\
(5.97)\end{array}$ & $\begin{array}{l}0.89 \\
(5.70)\end{array}$ & 84.78 \\
\hline $\mathrm{SE}(\mathrm{m}) \pm$ & 2.11 & 1.69 & 1.08 & 0.91 & 1.05 & 0.96 & \\
\hline CD (0.05) & 6.18 & 4.95 & 3.15 & 2.65 & 3.06 & 2.80 & \\
\hline
\end{tabular}

Table.2 Seed mycoflora of groundnut market samples collected from Karimnagar, Warangal, Nizamabad, Mahabubnagar districts of Telangana

\begin{tabular}{|c|c|c|c|c|c|c|c|}
\hline DISTRICTS & A. niger & A. flavus & Fusarium & Alternaria & Macrophomina & Penicillium & TFC (\%) \\
\hline Karimnagar & $\begin{array}{l}19.56 \\
(26.22)\end{array}$ & $\begin{array}{l}15.00 \\
(22.75)\end{array}$ & $\begin{array}{l}0.78 \\
(5.53)\end{array}$ & $\begin{array}{l}0.56 \\
(5.06)\end{array}$ & $\begin{array}{l}0.67 \\
(5.25) \\
\end{array}$ & $\begin{array}{l}0.67 \\
(5.26)\end{array}$ & 37.24 \\
\hline Warangal & $\begin{array}{l}21.89 \\
(27.83)\end{array}$ & $\begin{array}{l}19.22 \\
(25.91)\end{array}$ & $\begin{array}{l}0.78 \\
(5.51)\end{array}$ & $\begin{array}{l}0.78 \\
(5.45)\end{array}$ & $\begin{array}{l}1.00 \\
(5.98)\end{array}$ & $\begin{array}{l}1.33 \\
(6.54)\end{array}$ & 45.00 \\
\hline Nizamabad & $\begin{array}{l}16.67 \\
(23.99)\end{array}$ & $\begin{array}{l}13.67 \\
(21.61)\end{array}$ & $\begin{array}{l}0.78 \\
(5.45)\end{array}$ & $\begin{array}{l}0.78 \\
(5.51)\end{array}$ & $\begin{array}{l}0.44 \\
(5.25)\end{array}$ & $\begin{array}{l}0.44 \\
(4.79)\end{array}$ & 32.82 \\
\hline Mahabubnagar & $\begin{array}{l}25.00 \\
(29.91)\end{array}$ & $\begin{array}{l}26.22 \\
(30.70)\end{array}$ & $\begin{array}{l}1.44 \\
(6.80)\end{array}$ & $\begin{array}{l}0.78 \\
(5.51)\end{array}$ & $\begin{array}{l}0.67 \\
(5.97)\end{array}$ & $\begin{array}{l}0.67 \\
(5.33)\end{array}$ & 54.78 \\
\hline SE(m) \pm & 1.37 & 1.52 & 1.22 & 0.99 & 0.98 & 1.00 & \\
\hline CD (0.05) & 4.00 & 4.45 & 3.58 & 2.89 & 2.73 & 2.93 & \\
\hline
\end{tabular}


Fig.1 Seed mycoflora of groundnut farmer samples collected from Karimnagar, Warangal,

Nizamabad, Mahabubnagar districts of Telangana

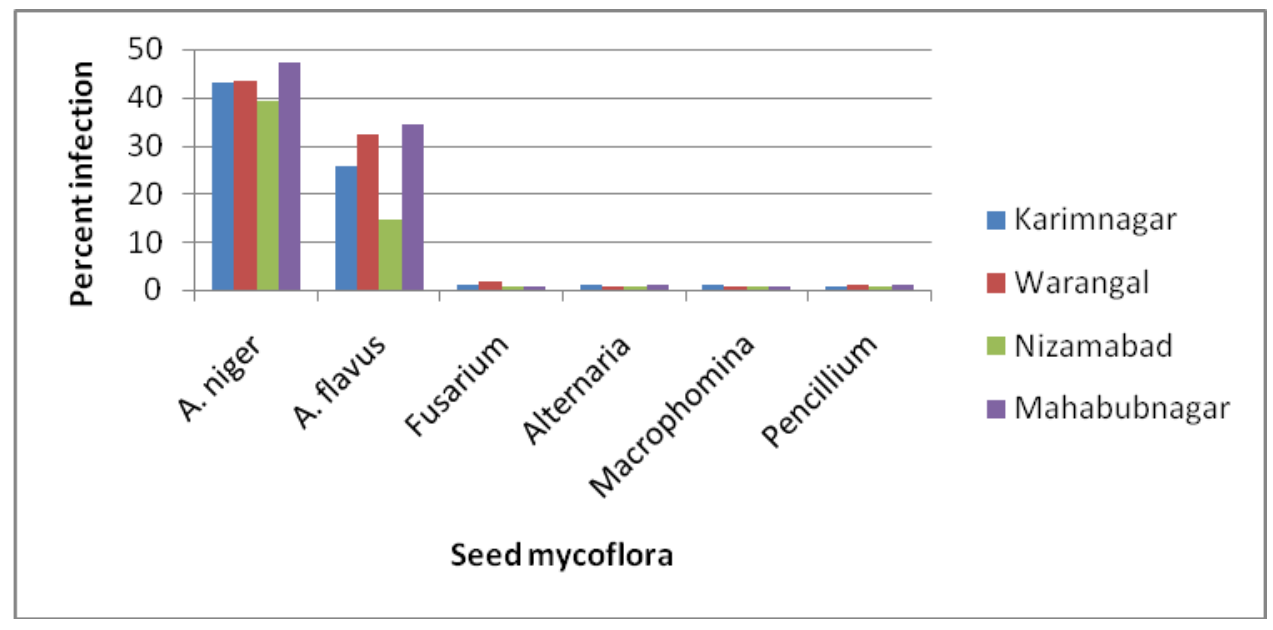

Fig.2 Seed mycoflora of groundnut market samples collected from Karimnagar, Warangal, Nizamabad, Mahabubnagar districts of Telangana

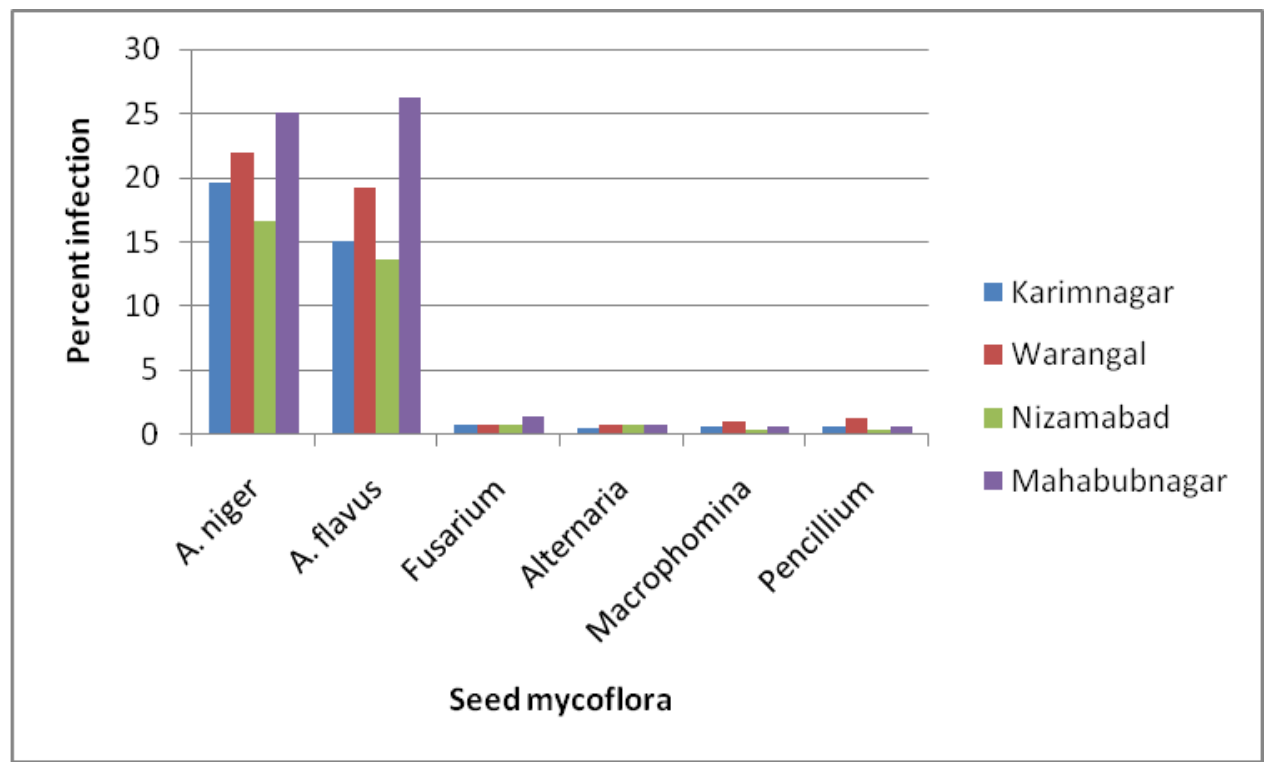

\section{Seed mycoflora of market samples}

Among samples collected from markets (Table 2) highest incidence was in Mahabubnagar (54.78 \%) followed by Warangal (45.00\%), Karimnagar (37.24\%) and Nizamabad (32.82\%) district. Samples collected from Mahabubnagar district were high incidence of fungal species with $A$. niger (26.22\%) followed by A. flavus $(25.00 \%)$,
Fusarium (1.44\%), Alternaria (0.78\%), Penicillium (0.67\%), and Macrophomina $(0.67 \%)$. Samples collected from Warangal district were high incidence of fungal species with A. niger (21.89\%) followed by A. flavus (19.22 \%), Penicillium (1.33 \%), Macrophomina (1.00\%) Fusarium (0.78\%) and Alternaria $(0.78 \%)$. Samples collected from Karimnagar district were high incidence of fungal species with A. niger (19.56 \%) 
followed by A. flavus (15.00\%), Fusarium (0.78 \%), Macrophomina (0.67 \%), Penicillium $(0.67 \%)$ and Alternaria $(0.56 \%)$. Samples collected from Nizamabad district were high incidence of fungal species with $A$. niger $(16.67 \%)$ followed by A. flavus (13.67 $\%)$, Fusarium (0.78\%), Alternaria (0.78\%), Penicillium $(0.44 \%)$ and Macrophomina (0.44\%) (Fig. 2).

\section{Risk and sensitive areas in Telangana}

In Telangana, two surveyed areas were categorized under risk zone for kernel infection (\%) by A. flavus and A.niger. Based on the mycoflora contamination in the pod samples, sampled in Mahabubnagar and Warangal districts were categorized as sensitive areas or risk zone. The other that fall in Nizamabad and Karimnagar districts were categorized as safe zone.

Our studies indicated that Telangana have significant levels of mycoflora contamination in kernels at farmers. Post-harvest contamination of groundnut pods during storage at farmers/markets in the present study is attributed to either the improper storage conditions or the carry over inoculums from field to farmers storage and ultimately to markets. Improper storage practices are the major factors during storage. Pod storage at high moisture levels increases post-harvest molding. Besides, storing the pods at optimum moisture levels, pod drying by farmers immediately after harvest also helps in reducing the infection during storage. Inverted windrowing is an ideal drying procedure of pods after harvest. It helps in proper drying of pods with adequate exposure to sunlight.

From among the Aspergillus species isolated in the current study, it is also agreement with Guchi et al., (2014) A. flavus and A. niger were more prevalent species infecting groundnut samples collected from farmers' fields than from farmers stores, market retailers and vendors in the five agroecologies of eastern Ethiopia. Present study also agreement with groundnut seeds collected from store house and oil mills of Warangal district were infested by different seed borne fungi varying in percentage different sample conditions and place of collection (Kalyani et al., 2014). The finding of the present study is in agreement with the findings of Abdi and Alemayehu (2014) who reported that groundnut samples collected from farmers' fields and farmers store houses in Babile and Gursum districts had 80 and 70 $\%$ kernel contamination, respectively, by Aspergillus species. Present results showed that $A$. flavus and $A$. niger were the predominant fungi of groundnut which are similar to studies conducted by Mukherjiiet al., (1992) and Naqui et al., (2013). They also found that A. flavus and A. niger were the predominant storage fungi of groundnut seed and also compared with results found with Rasheed et al., (2004). These results are also agreement with the A. flavus (72\%) gave highest percent incidence followed by $A$. niger $(68 \%)$ and $F$. oxysporium (55\%) (Rathodet al., 2012).

In conclusion, the study has demonstrated a high prevalence of the fungi associated with groundnut kernels. Aspergillus sp. is an important fungi associated with groundnut seeds. However, their occurrence and level of infection is more or less similar among all the locations. The fungi Aspergillus sp. association with seed is a likely to be a threat in storage as it increases its infection under improper storage conditions. Hence, there is a need for reducing the mold growth and mycotoxin production by improving the storage conditions. There is also a need to increase public awareness among farmers in aspects of seed health because presence of so many pathogenic fungi could be an indicator 
of poor soil health. Awareness in this direction can help the farmers to develop suitable management practices for improving the quality of harvest.

\section{Acknowledgements}

Authors acknowledge the ICRISAT for the financial support to undertake this study through its CGIAR Research ProgramAgriculture for Nutrition and Health (CRPA4NH).

\section{References}

Agarwal V. K. 1976. Technique for the detection of seed borne fungi. Seed Research. 4: 24-31.

Abdi, M. and Alemayehu, C. 2014. Incidence of Aspergillus contamination of groundnut (Arachis hypogaea L.) in Eastern Ethiopia. African Journal of Microbiology Research. 8(8): 759-765.

Bankole, S.S., and Adbanjo A. 2003. Mycotoxins in West Africa current situation and possibilities of controlling it. African Journal of Biotechnology. 2: 254-263.

Cotty, P.J. 1994.Comparison of four media for the isolation of Aspergillus flavus group fungi. Mycopathologia. 125: 157162.

Craufurd, P.Q., Prasad, P.V.V, Waliyar, F and Tehri, A. 2006. Drought, pod yield, pre harvest Aspergillus infection and aflatoxin contamination on peanut in Niger. Field Crops Research. 98: 20-29.

Dharmaputra, O.S., Retnowati, I., Putri, A.S.R and Ambarwati, S. 2003. Aspergillus flavus and aflatoxins in peanuts at various stages of the delivery chain in pati regency, Central Java.

Egel, D.S., Cotty, P.J. and Elias, S. 1994. Relationship among isolates of Aspergillus section Flavi that vary in aflatoxin production. Phytopathology.
84: 906-912.

FAOSTAT, 2014. Food and Agricultural Organization statistics database (FAOSTAT)

$<$ http://faostat.fao.org/site/567/Desktop Default.aspx ?PageID=567\#ancor $>$.

Goncalez, E., Nogueira, J.H.C., Fonseca, H., Felicio, J.D., Pino, F.A and Correa, B. 2008. Mycobiota and mycotoxins in Brazilian peanut kernels from sowing to harvest. International Journal of Food Microbiology. 123: 184-190.

Guchi, E., Ayalew, A., Dejene, M., Ketema, M., Asalf, B and Fininsa, C. 2014. Occurrence of Aspergillus species in groundnut (Arachis hypogaea L.) along the value chain in different agro ecological zones of Eastern Ethiopia. Journal of Applied and Environmental Microbiology. 2(6): 309-317.

ISTA. 1966. International Rules of Seed Testing. Proceedings of International Seed Testing Association. 32: 565-589.

Kalyani, S., Kiran, S., Surekha, M and Reddy, S.M. 2014. Incidence of mycotoxigenic fungi on peanut seeds of Warangal district of A.P. Indian Journal of Applied Research. 4(2): 4-6.

Kurtzman, C.P., Horn, B.W. and Hesseltine, C.W. 1997.Aspergillus nomius, a new aflatoxin production species related to A. flavus and A. tamarii. Antonie Van Leeewuwenhoek, 53: 147-158.

Muskett, A.E. 1948. Technique for the examination of seed for the presence of seed borne fungi. Transactions of the British Mycological Society. 74 - 83.

Mukherjee, P.S., Nandi, S.K and Nandi, B. 1992. Deteriorative changes in groundnut seeds in storage. Journal of Mycopathological Research. 30(2): 113-119.

Naqvi, S.D.Y., Shiden, T., Merhawi, W and Mehret S. 2013. Identification of seed borne fungi on farmer saved sorghum (Sorghum bicolor L.), pearl millet 
(Pennisetum glaucum L.) and groundnut (Arachis hypogaea L.) seeds. Agricultural Science Research Journals. 3(4): 107-114.

Okuda, T., Klich, M.A., Seifert, K.A. and Ando, K. 2000. Integration of Modern taxonomic methods for Penicillium and Aspergillus Classification. Samson, R.A. and Pitt, J.I. (eds.), Hardwood Academic Publishers, Reading, UK. pp $83-100$.

Ramamoorthy, K and Karivaratharaju, T.V. 1989. Influence of pod and kernel treatments on the field performance of groundnut (Arachis hypogaea. L.) cv.
Pol.2 after twelve months of storage. Seeds Farms. 15: 15-19.

Rasheed, S., Darvar, S., Ghaffar, A and Shakut, S.S. 2004. Seed borne mycoflora of groundnut. Pakistan Journal of Botany. 36(1): 199-202.

Rathod, L.R., Jadhav, M. D., Mane, S. K., Muley, S.M and Deshmukh, P. S. 2012.Seed borne mycoflora of legume seeds. International Journal of Advanced Biotechnology and Research. 3 (1): 530-532.

Statistical year book of Telangana, 2015.

\section{How to cite this article:}

Adithya, G., B. Rajeshwari, K. Keshavulu, H. Sudini and Swathi, Y. 2017. Mycoflora Associated with Groundnut Seeds Collected from Selected Groundnut Growing Districts of Telangana State, India. Int.J.Curr.Microbiol.App.Sci. 6(7): 4335-4342. doi: https://doi.org/10.20546/ijcmas.2017.607.451 